\title{
Kant and Religion Roundtable
}

\author{
Allen Wood $^{1,2}$ \\ ${ }^{1}$ Indiana University, Bloomington, IN, USA and ${ }^{2}$ Stanford University, Stanford, CA, USA \\ Emails: awwood@indiana.edu, allenw@stanford.edu
}

\begin{abstract}
This article provides a summary and some replies to points offered in the Kantian Review Roundtable discussion of my recent book Kant and Religion. The main themes are as follows: Kant's project in the Religion; religious thinking as symbolic; the rational interpretation of revelation and of religious symbols; Kant's moral argument for religious faith; the 'psychological'-moral argument; Kant's thesis that human nature contains a radical propensity to evil; evil and human sociability; evil and freedom; divine forgiveness and the sinner's self-acceptance; Kant's Religion as a subject of philosophical controversy.
\end{abstract}

Keywords: Kant; religion; symbol; God; moral argument; evil; freedom; forgiveness

For Kant, 'religion' means recognizing all your duties as divine commands. Kant thinks it is possible to be a morally good person without being religious in this sense, but also that rational morality gives us reasons for being religious. My recent book Kant and Religion (Cambridge, 2020) is focused on Kant's project in a specific work: Religion within the Boundaries of Mere Reason. This work is really about Kant's encounter with the Christian faith, his attempt to interpret Christianity from the standpoint of reason and rational morality, and to make a case to his Christian (even more specifically, his Lutheran) contemporaries that they could not only combine their religious life as Christians with rational morality, but also that doing so would enrich their lives both as faithful Christians and as rational moral agents.

I thank the authors of the other contributions to this Roundtable who discuss my book for giving it their thoughtful attention. Where they are critical, the following discussion will address the substance of some of their criticisms, but will not address the critics by name. There is no space here for me to explore all their remarks in the detail needed to do them justice. I leave it to readers to litigate for themselves the differences between my position and those of my critics. Thinking critically about exchanges like this one is how philosophy makes progress.

\section{Kant's project in the Religion}

Kant's attempt to show that the Christian religious life can be combined harmoniously with rational morality brought him into conflict with the Prussian authorities, 
who accused him of appraising and disparaging the Christian religion. Some even today think there is merit in the charges brought against him. Of course it is always possible for someone hostile to Kant to define 'Christianity' in ways that would put Kant's claims, and his entire project, in disagreement with Christianity so defined. This obvious truth is not worth debating. But Kant himself denied that he was appraising or disparaging Christianity; anyone who says he was is plainly disagreeing with him, and also thereby rejecting fundamental claims of Kant's Religion. My project was to expound sympathetically Kant's project of establishing a religion of mere reason, along with its mutually supportive relation to Christianity.

Kant presents religion as consisting of two concentric circles. The central one is a pure rational religion, and the wider one a religion based on alleged empirical revelation from God (Religion, 6: 12). ${ }^{1}$ Kant distinguishes the task of the biblical theologian, who interprets scripture authoritatively for a church, from the philosophical theologian such as himself, who seeks to interpret religious doctrines for a religion of reason. Kant's project in the Religion is not to compare the two (as if they might either agree or disagree) but to show that when revealed religion is rightly interpreted, they need not disagree. Kant's project in the Religion is to take fragments of revealed Christianity and show how they lead back to the inner circle of rational religion. Kant thinks that this project should be done for every religious tradition, though in the Religion his aim is to do it only for Christianity.

Kant's project can best be seen in terms of a kind of historical hope it represents. This is a hope, on the one hand, for the Christian faith and on the other for the human culture of which that faith is a living part. Kant hopes that Christianity will reform and reinterpret itself in a way that enables Christians to see that a moral religion of pure reason is the kernel within the hull of revealed Christian faith. Kant also hopes that human society will become centrally an ethical commonwealth or people of God, so that religious life becomes the animating force of cultural life as a whole. The religion of reason, which is the referent of the title of Kant's Religion within the Boundaries of Mere Reason, represents the attempt to further these hopes by offering revealed faith interpretations of its doctrines that bring them into harmony with reason and therefore advance the reform of revealed faith. As we will see shortly, this project is centrally the rational interpretation of symbols, since all religious thinking is symbolic.

It is now difficult for us to share Kant's religious hopes, perhaps hard even to understand them. Both religious and non-religious people today are apt to perceive Kant's hopes as a threat. The religious are likely to see Kant's rational religion as an encroachment on their faith by a hostile secularism, while non-religious people, or even just non-Christians, are apt to fear Kant's ethical community as the colonization and totalitarian takeover of our freedom by institutions representing backward religious dogmatism and authority. We tend to see modern society as a cultural battle to the death between religion and secularism. It was the aim of my book, however, to reject that sick picture. Kant wants Christianity to evolve in such a way that it is harmonious with enlightened reason, and human culture to evolve in a way that religious thinking, and Christianity in particular, will enrich and promote human freedom, along with science, art and other aspects of our collective life. It is pernicious to frame things in terms of religious culture wars between religion and secularism. It would be hard to get things farther wrong than to see my presentation of Kant as 
taking up one side or the other in the culture war between religion and secularism. That cannot be stressed strongly enough.

\section{All religious thinking is symbolic}

One important and fundamental Kantian thesis about religious thought and cognition is that they are symbolic. Kant is explicit and even insistent about this: 'All of our cognition of God is merely symbolic, and anyone who takes it ... as schematic falls into anthropomorphism, just as if he leaves out everything intuitive, he lapses into deism, by which nothing is cognized even from a practical point of view' (Critique of the Power of Judgement, 5: 353, cf. Anthropology, 7: 191-2, Progress in Metaphysics, 20: 279-80, 332).

It is an important Kantian thesis about both thinking and cognizing that they require a combination of the conceptual and the intuitive. When concepts are a priori (such as the categories) they can be employed cognitively only through schemata, which are direct presentations of the concept in intuition. An idea of reason, such as the idea of God, is also a priori, but incapable of being schematized. Here the intuitive must take the form of an indirect presentation, which Kant calls a symbol. Symbols operate through analogy, by which Kant means not a similarity in objects but a sameness in the way of thinking about them. All thinking about God must involve representations that do not tell us directly anything about God's nature, since we cannot cognize that (Prolegomena, 4: 357n.). Instead, religious symbols express practical principles having religious significance or evoke religious feelings and aesthetic ideas. The task of rational religion is to interpret the symbols of revealed or ecclesiastical religion in a way that harmonizes revealed faith and reason, promoting the rational reform of religious communities.

To ignore or dismiss the role of symbols in Kant's thought about religion is a serious error. We may be tempted to contrast symbolic readings of religious texts or doctrines with literal readings. We may think that the literal is what matters and symbols are mere decoration. We may then speak dismissively of the symbolic in religion, such as by saying that for Kant religious thinking is 'only' or 'merely' or 'just' symbolic, as if to call it symbolic is to say it is inferior to or less meaningful than what is 'literal'. We sometimes say something is 'just symbolism' when we mean to contrast empty 'merely symbolic' actions with actions that are genuine, substantive or effective. Regarding religious symbolism, as Kant understands it, these thoughts get everything upside-down and backwards. If you approach Kant with such assumptions you will get everything entirely wrong. For Kant, a merely 'literal' reading of religious texts or thoughts would thereby be non-religious. Or if there were such thoughts, they would have to take the form of anthropomorphism, which superstitiously reduces God to a kind of personified natural force, a monstrous tyrant. Genuine religious thought is always symbolic, not 'literal'. Religious thought lives essentially through symbols and their interpretation, not only in theological thinking but in life. If believers insist they are thinking or speaking literally, that does not make it true. It means only that they misunderstand the nature of their own religious thinking.

of course some statements made in scriptures must be taken literally, as when they make claims about the geography of the Holy Land or the history of past events. But even these are sometimes also best understood symbolically if they are to have 
true religious import. The story of the Exodus, for instance, symbolizes the human aspiration for liberation and the hope that God will help any oppressed people free itself. Kant realizes that many scriptural accounts do have a literal meaning for their human authors, and he insists that we must not twist the words of scriptures when we are talking about the intent of their human authors. But Kant insists that if it is a matter not of the intent of the teacher but of the religious meaning of the teaching, we must always recognize that what is being said is symbolic rather than literal. Otherwise, he says, the true sense, which is the final end, would be lost (Anthropology, 7: 192). It is not only when God is being spoken of directly that symbolism is important. In the Religion, Kant repeatedly insists that all Christian scriptures and doctrines must be read symbolically if their practical import, which is what really matters, is to be grasped (Religion, 6: 171-2, cf. 80n., 110n, 111, 134, 136, 176).

Symbolism operates by analogy. An analogue is something we use to represent another thing because the way we think about the two things is the same. We think of God as willing, commanding and judging by thinking of him, as far as possible, in the same way we would think of a morally perfect human being who wills and acts. But this is difficult and also places on us the responsibility to interpret rationally the thoughts we have about God. It would be possible to represent God without symbolism but only in two ways, both of which make true religion impossible. The first way is deistic (in Kant's technical and somewhat idiosyncratic sense of that term). We represent God as a metaphysical ens realissimum instantiating only ontological predicates but no personal predicates such as understanding or will. Since religion for Kant is regarding your duties as commanded by a personal God, a deistic God excludes religion.

The other way, anthropomorphism, is far worse. It thinks of God literally, not symbolically, as a personified natural force possessing the powers of a human tyrant. This is superstitious in Kant's sense of the word: using your understanding in ways that violate its own essential rules (Critique of the Power of Judgement, 5: 294). This is monstrous morally as well as cognitively. It is also idolatrous, because it worships an anthropomorphic delusion of ours in place of the true God. Kant agrees with the major theistic religions - Judaism, Christianity and Islam - in viewing idolatry as a perpetual danger to true religion. Kant was a sharp critic of the abuses found in popular religious culture: anthropomorphism, idolatry, enthusiasm, fetishism, priestcraft and statutory counterfeit service of God (Religion, 6: 141 and Part Four; Critique of the Power of Judgement, 5: 459n., Anthropology, 7: 192; Lectures on the Philosophical Doctrine of Religion, 28: 1046, 1117-18). It is no wonder religious 'literalists' try to tone down this part of his message.

Among Christian theologians, the one who has most emphasized the importance of symbols is Paul Tillich. Although I do not think we can simply identify Kant's views about religious symbolism with Tillich's, it is important to see that Kant is a precursor of Tillich, and that both represent a significant position in Christian theology. I admit my own sympathies in theological matters are Kantian or Tillichian. But the main reason I emphasize the role of symbolism in expounding Kant is that there is no way to understand the project of Kant's Religion without appreciating the importance of symbols for his conception of religious thinking. 


\section{The interpretation of symbols}

How far does Kant think the interpretation of religious symbols is subject to our arbitrary choices? Is each of us supposed to be free to make of religious symbols whatever we like, so that they suit our private preferences and fancies? That would be a shallow way to read Kant. But religious people always do implicitly interpret symbols through the way they live. And of course they should be free to do this. In my book I wrote 'Kant is presenting for his readers' consideration what his reason tells him; he is not claiming to dictate what yours must tell you.' But the point was not that Kant's reason is 'subjective' or valid only for him. The point was rather that religion should not be subject to external coercion. Kant was opposed to creeds, catechisms and ecclesiastical authorities dictating to people what they should believe. In religion as in everything else, people should think for themselves, using their own reason. But reason always seeks what is universally valid, valid for all of us. That applies to 'what Kant's reason tells him' and you should apply it to 'what your reason tells you'.

The interpretation of religious symbols is not a 'secular' activity but wholly religious in aim and content. It should engage the full range of our moral and emotional capacities. It is not a matter for arbitrary caprice any more than moral choice itself is. Kant had no intention to challenge the authority of Lutheran ecclesiastics or biblical theologians in the theology faculties of universities when it comes to what the established church regarded as orthodoxy. But of course he might try to change their minds on some matter by reasoning, and it is the aim of the Religion to begin, at least, to work out a 'pure rational system of religion' (Religion, 6:12) to be used in interpreting doctrines of revealed religion. But Kant had no aspiration to impose it on others coercively after the manner of a civil or ecclesiastical authority.

I have mentioned that Kant was accused by the Prussian authorities of disparaging Christianity. In my book I tried to explain and defend Kant's reply, which is that his only aim in the Religion was to appraise only a possible religion of pure reason, and also to see how far revealed Christian doctrines can lead back to it, thereby offering a way of understanding and also of accepting them. Kant concluded that this project could not be interpreted as appraising Christianity or especially as disparaging it (Conflict of the Faculties, 7: 8-9). But as I have already implied, I do not for a moment deny that if someone looks at the issues with the hostile assumptions of the Prussian censors - or on the other side takes the equally hostile standpoint of a dogmatic secularism that pits reason against Christianity - then they can conclude that Kant was guilty of the charges brought against him. I do not apologize for choosing the standpoint of an Enlightenment religious philosopher and rejecting both these antiKantian alternatives.

Interpretations of Christian doctrine suggested by Kant may seem to some to involve contradicting, rejecting or negatively appraising 'literal' Christian doctrine. But what is called 'literal' is often only a traditional or dogmatically accepted interpretation. Kant's interpretations are never arbitrary or just his personal preferences; they are grounded on rational moral principles. Here are some examples: Kant thinks we cannot literally inherit sin or evil character from our ancestors, since nothing of that could be imputed to us. Our evil propensity could not wipe out our personality or capacity for goodness, since then it could never be regained and we could no longer even be held responsible for our (supposedly evil) actions. Sinfulness, and also the 
conversion of our disposition from evil to good, must be imputable to us as our own deed, even if we also believe (what Kant thinks can never be proved or disproved, since it would be unknowable by us) that the conversion was made possible wholly through God's grace. And it could never be just for one human being, who is innocent, to suffer as punishment for the sins of a different human being. Nor could a good God ever command a father to slaughter his innocent son as he might sacrifice a sheep. However 'literal' (or dogmatically traditional) they might be, these ways of understanding biblical doctrines would violate basic moral principles; the symbols must be interpreted differently, so that they can support true morality. Kant cannot presume to tell Lutheran ecclesiastics or biblical theologians what is orthodox Christianity, but he can argue that their own reason should lead them to avoid interpretations of Christian symbolism that make no moral sense or violate rational moral principles.

Of course if you identify Christian beliefs only with a 'literal' (that is, a traditional and authoritatively accepted) interpretation of them, as no doubt Wöllner and the Prussian censors did, then of course you will have to agree with their judgement that Kant was negatively appraising Christianity when he proposed to interpret Christian beliefs symbolically through concepts and doctrines of pure rational religious faith. The Prussian censors cared only about whether people would repeat the words they had been taught, assenting to the dead letter of doctrine, giving unthinking slavish obedience to the religious idol just as they do to commands of the secular despot. So they understandably saw a philosophy and a rational religion that involves the rational interpretation of symbols as a threat to their dogmatic authority. But if you see things in Kant's way, you will argue that this not only misunderstands Kant but also misunderstands Christianity and even subverts true religion in general. Taking Kant's side in this matter is not taking the side of 'secularism' against 'religion', but taking the side of enlightened religion against a backward and unenlightened dogmatic state authority.

Several of my specific discussions in Kant and Religion have become matters of controversy. I doubt that these controversies can be laid to rest in this brief discussion, but I will address them just the same, so as to have my say and hopefully advance the conversation.

\section{Kant's moral argument for faith; the 'psychological'-moral argument}

Basic to Kant's position is his argument that, although one can be a morally good human being without being religious, rational morality itself provides good reasons for faith in God and for regarding duties as divine commands. Chapter 2 of my book tries to present sympathetically Kant's so-called 'moral argument' for practical assent to the existence of God. Like any philosophical argument with such ambitious aims, there are always ways it can be challenged, and there is no space here to deal with all the ways Kant's argument can be misunderstood or with all the objections quibblers might raise. The argument concerns the rational demands of setting an end and assenting to the conditions of its actualization. My book argued that something like Kant's argument should be relevant to all those who devote their lives to a great cause that must outlive those loyal to it. 
Another argument for practical assent to God's existence has been suggested under the name 'psychological'-moral argument. I don't understand it and I don't want to be unfair to it. So I will explore two possibilities. I can accept it if the import of the 'psychological' argument is that we should assent to God's existence on the practical grounds Kant offers, and the resulting rational assent (or Belief) serves to combat our moral weakness. But I must point out that, for Kant, his moral argument is not meant to alter our character. Its aim is to bring our rational assent into harmony with a good moral disposition. 'It is not meant to convince the doubter that there is a God but only to prove that if his moral thinking is to be consistent he must include the acceptance of this proposition among the maxims of his practical reason' (Critique of the Power of Judgement, 5: 450-1n.). Kant's argument is not meant to make (or to keep) the 'righteous Spinoza' righteous. It is only to show him to what convictions his righteousness commits him according to practical reason (Critique of the Power of Judgement, 5: 452).

Suppose, however, that the idea of the 'psychological' argument is different. You reject Kant's argument but replace it by psychologically manipulating your intellect, contrary to your reason, planting in yourself some belief or assent you hope will turn you into a kind of person you know you are not but wish you were. The problem is: that way you cannot make yourself into a better person, only a worse one. For you have no reason (whether theoretical or practical) to believe. You are just practising a self-deception on yourself, based on an indirect 'end justifies any means' rationalization. It is a lie to claim you have a reason for what you believe when all you have is this imagined psychological need. Suppose you want to square yourself with the little Cliffordian evidentialist inside your head and think it more innocent to inflict on yourself acts of assent that fall short of belief. Surely that would have less influence on your behaviour than a belief, hence it would be less likely to achieve your corrupt psychological aims. But you are still not fighting your despair and moral weakness, but surrendering to them. If you really want to fight your moral weakness, you need to start being honest with yourself. Stop trying to stage-manage your mind.

Kant says that the rational assent produced by the moral argument is 'conviction' (Überzeugung): 'the possibility of communicating it and finding it valid for the reason of every human being' and not mere 'persuasion' (Überredung): an assent consciously valid only subjectively for oneself (Critique of Pure Reason, A820-2/B848-50; Critique of the Power of Judgement, 5: 461). But persuasion seems the most that could be delivered by an alleged psychological need based on the self-pitying consciousness of your own moral weakness. Kant says about persuasion that it cannot justify even assertion to anyone else. If so, then such persuasion a fortiori could not result in anything that could honestly be called an argument. It would be only a sad, self-indulgent sophistry. No self-respecting Spinoza would ever soil his righteous fingers by touching it. But again, I am not sure the 'psychological' argument is either of the two possibilities I have just explored, and if it is neither, then I do not know what it could be.

\section{Radical evil}

A second issue concerns Kant's attempt to provide a rational or philosophical interpretation of the Christian doctrine of original sin, in the form of the thesis that human nature contains a universal, innate and inextirpable radical propensity to evil. One 
issue that has come up about this is whether that doctrine of rational religion receives from him, or could receive from others, an a priori transcendental (or 'quasi-transcendental') proof. It was not my purpose in the book to examine all the attempts to argue the affirmative, but I did argue that Kant's texts make it clear that he himself took the negative. And I rest my case with that.

For one thing, Kant himself is quite clearly not unqualifiedly committed to the thesis of radical evil. His assessment of the character of the human species at the end of the Anthropology (several years after the Religion) does not explicitly deny the radical evil thesis, but it does say that in the progress toward morality 'our volition is in general good' (Anthropology, 7: 333). He therefore seems to side more with what the Religion called the 'more recent and heroic' view of human nature rather than the ancient view 'of the priests' that 'the world lieth in evil' (Religion, 6: 1920; cf. John 5:19).

Kant never claims to offer any proof of the thesis of radical evil. After asserting the thesis and presenting some evidence for it, Kant concludes that it is useful in rational religion only for moral discipline, not for moral dogmatics (Religion, 6: 50-1). He also says early in his discussion of it (and he never retracts this) that it can be proven, if at all, only 'later on' (weiterhin) by 'anthropological research' (6: 25). Kant never uses any term (e.g. 'transcendental' or 'deduction') suggesting an a priori proof. I cannot examine in detail the different (and often tortured) arguments of the various scholars who claim there is such a proof. But it is fairly clear that they do not agree even among themselves what the proof is or even what thesis is to be proven. They seem to disagree with one another as much as they disagree with me. For some, radical evil seems to be a far weaker thesis than Kant's, such as that we are aware of committing evil, or aware that it is possible for us to commit evil. But I still can find nowhere in Kant's texts anything like an attempt at an a priori or 'transcendental' proof even for their weaker theses.

\section{Evil and unsociable sociability}

In the First Part of the Religion, Kant characterizes our predisposition to humanity as involving a propensity to compare ourselves with others and consider ourselves happy only when we stand higher than they do in that comparison (Religion, 6: 27). Then at the beginning of the Third Part, he argues that while it is evident that each of us is wholly responsible individually for the evil we do, it is also easy to convince oneself that what draws us into the danger of committing evil is our relationship to others of our kind, to whom we stand in competitive and hostile relationships, even though these do not preclude also the possibility of mutual love (6: 93-4). I have never wanted to make any claims about this beyond what Kant himself says explicitly in the passages to which I have just referred. In the literature, however, the position I have just attributed to Kant (simply because I found it right there explicitly in his texts), is sometimes called 'Wood's social interpretation of evil', and it is claimed that it must be a misinterpretation, either because it cannot take account of the 'noumenal' context of evil, or because it would entail that we could blame our evil on other people, or because it cannot account for violations of duties to ourselves.

That for Kant the radical evil in human nature has the social context of competitiveness, envy and jealousy was first brought to my attention in November 1986 by 
the late Sharon Anderson-Gold. So I can claim no exclusive ownership of this observation. If people want to reject the claims Kant makes in the passages just cited, however, I wish they would say it that way, instead of criticizing me for quoting Kant, saying that he says what he says, and trying to make sense of it. It is his thesis they are disputing, not mine or Anderson-Gold's.

I should also observe that Kant never presents the social context of the human propensity to evil as its source, or any sort of explanation of evil. Kant is emphatic that human evil is inscrutable (unerforschlich): he says we cannot help asking about why we commit evil volitions, or why we have an innate propensity to them, but can never answer the question (Religion, 6: 25). In my book I reply on Kant's behalf to the charges that his claims about the social context of evil are inconsistent with Kantian doctrines; I try to show they are perfectly consistent when these doctrines are properly understood. I think these scholars could learn something about the way Kant conceives of both human freedom and human sociality if they came to see how his doctrines here are all self-consistent.

One suggestion in the literature is that the social context of evil would threaten our individual responsibility for the evil we do. Another is that when Kant says it is 'easy to convince oneself' of the social context of evil he means this is a deception we practise on ourselves to evade responsibility. But Kant's texts provide no evidence whatever that he thinks either thing. If anyone offered such an excuse for his own evil deeds, that would be comparable to people who seek to evade responsibility by saying 'the Devil made me do it' or rapists who blame their crimes on the way their victims were dressed. I do not think that those who question the social context of evil on these grounds themselves seriously believe that we would be less responsible for our misdeeds just because our social condition tempted us to them. That shabby thought involves such a conspicuously corrupt sophistry that it could not pose any objection to the claim that there is such an association of evil with unsociable sociability.

On this matter Kant follows Rousseau, who views the social condition as the context in which our reason develops, together with our culpability for evil and our distinctively human kind of wretchedness. Kant holds that the culpability for evil is always individual, but the context in which it develops is social. Our social life corrupts us, but we as individuals bear the entire responsibility. The position of Rousseau and Kant is that evil must be our moral burden as individuals, but society too must be changed or even revolutionized. I admit, however, that I do find this view attractive, as did some other eighteenth-century figures, such as Adam Smith and Denis Diderot. Kant's view of evil is a characteristically socially progressive Enlightenment position, which Marx also followed. As a law student, the latter was particularly taken with this problem and with the social context of crimes.

\section{Is the propensity to evil compatible with freedom?}

One worry sometimes expressed about Kant's thesis of radical evil is that the claim that the radical propensity to evil is universal among human beings threatens the presupposition that it results from freedom. If we equate universality with necessity, and necessity precludes freedom, then Kant's commitments seem inconsistent. The plain resolution of this problem, of course, is that Kant's claim that evil is universal 
is made because he is trying to offer a rational version of the Christian doctrine that we are all sinners. Of course Kant never says that radical evil is necessary or inconsistent with our freedom. Again, the strongest claim he ever makes on behalf of the universality of evil is that 'anthropological research' might 'later on' (weiterhin) be able to show that there is 'no reason to exempt' any human individual from it (Religion, 6: 25).

That Kant's radical evil thesis might make evil necessary (hence incompatible with human freedom) might be a danger for those who think there is some kind of a priori proof for it, since an a priori proof might present the thesis of radical evil as a necessary truth. But this danger goes away if we realize that the thesis is empirical and contingent, especially if for Kant the universality of evil has not yet been proven. Again, Kant's commitment is only to the claim that the thesis of radical evil is plausible enough to be asserted as useful to 'moral discipline', and not anything demonstrated by 'moral dogmatics' (Religion, 6: 50-1).

People also object that they do not know how the universality of a propensity to evil might be confirmed by anthropological research. But until an alleged confirmation of the thesis is actually offered, it is premature to worry about what it might consist in. Kant's own arguments - the 'crying examples' of evil found among different kinds of human beings - might be sufficient to make the thesis usable in moral discipline, which is all that Kant ever claims. If we distinguish the claims Kant actually makes from the oversimplified and exaggerated claims falsely attributed to him in the literature, then I suggest that this problem disappears.

\section{Divine forgiveness and self-acceptability}

Another issue I should address is this. In the book I say that I think the question whether I can hope to be well-pleasing to God is a symbolic religious way of asking the question whether I can be acceptable to myself. Some have suggested that this amounts to attributing to Kant some form of human self-deification, representing myself as 'my own saviour' or reducing divine grace to some 'secular' substitute for it. Of course all these claims, if I had put them forward as an interpretation of Kant, would be untenable and even offensive. None of them are any part of what I meant, and all of them represent a lamentable misunderstanding of whatever I said that suggested such silly thoughts to anyone.

If you are tempted to think my reading involves anything of this sort, then you had better go and read Kierkegaard's The Sickness unto Death (written under the pseudonym Anti-Climacus) - which I cited in a footnote to this discussion. The whole point of that work is to argue that my God-relationship is the right context in which to see the self-question: the either/or of self-volition or despair - whether I can or cannot will to be the self that I am. Kant was anticipating Kierkegaard when he connects my moral self-judgement in conscience with my God-relationship. No more than Kierkegaard (or his hyper-Christian pseudonym) is Kant (or am I) trying to turn a religious issue into a secular one or (nonsensically) make you into your own saviour. What I said in the book was that for Kant the ethical question of my acceptability to myself is best seen in religious terms: as my second-person relation of striving to be well-pleasing to God. 
The real point here, I believe, is once again the meaning of symbolism in Kant. For my guess as to what motivates the critics is the notion that nothing said to be symbolic is ever really meant, so that when we say divine forgiveness is meant symbolically, we can never be talking about anything we seriously mean, but are only expressing some subjective (perhaps blasphemously self-deifying and odious) 'secular' substitute for a genuine religious thought. But I repeat that this gets everything upside-down and backwards. For Kant, all religion thinks symbolically, whether it realizes it or not. It is possible to lose sight of this point innocently, relating to God through symbols without being conscious of it or even while erroneously believing one is thinking and speaking literally. We then live the human meaning of religion through the interpretation of symbols, as true religion must, even if we are in denial about it. But if we stubbornly treat the symbol as if it were the reality symbolized, that would be idolatry.

The superstitious tendency to anthropomorphism and idolatry runs deep. Some may think that only what is meant literally is really meant or really believed; what is 'merely symbolic' is just so much 'secular' pretence, fiction or flat-out lying. There is a strong temptation to treat any philosopher or theologian (such as Kant or Tillich) who insists on the symbolic character of religious thoughts as using symbolism as a pretext for replacing the true God with some arrogant philosopher's arbitrary opinion. But as Kant sees it, this gets everything backwards. Only through symbolism is true religion possible. Symbolic representation does not reduce or deflate the divine. We experience our moral life through symbolic religious representations in order to present matters of moral importance in ways that are both illuminating and also aesthetically or emotionally powerful and significant. Since all religious thought is symbolic, the rational interpretation of symbols is not a reduction of the religious to the 'secular' but an indispensable function of religious life itself.

If, reflecting on the symbolic character of my God-relationship, I say that I think about being acceptable to myself in terms of my being well-pleasing to God, this is not a way of reducing the thought of God to the thought of myself. On the contrary, it is a way of presenting my relation to myself, as self-judge, in a more morally significant way than I can merely through my judgement of myself in fallible human terms. That is why Kant thinks of conscience, the inner court of self-judgement, as appropriately symbolized as the judgement of God (Metaphysics of Morals, 6: 438). To say it is symbolized is not to say it is less meaningful than literal thoughts. Just the reverse: it is literalism that deflates and reduces religion to anthropomorphism, superstition and idolatry.

The grain of truth in the shallow, dismissive thought that symbolism in religion leaves everything up to our subjective, arbitrary opinions is that it does place on us the responsibility to interpret the symbolism based on our own reason and to understand why the symbols are meaningful to us. Literalism in religion can easily serve as a flight from that responsibility. Kant would also call it a retreat from enlightenment into a form of self-incurred minority in which we defer to the letter of religious tradition instead of appropriating its spirit.

\section{Controversies about Kant and religion}

One thing emphasized in Kant and Religion is that it is about Kant and the Religion, not about the very sizeable literature on Kant's religious thought produced since my first 
book a half century ago. I could not discuss in detail all the other scholars who have written about Kant on religion, pursue all the subtleties of their interpretations, or give their due to those with whom I disagree. I do not think any scholar on any topic as large as this can ever do that with all the pertinent literature. Unresolved controversy is the inevitable fate of any philosophical discussion. When I discussed this literature, it was only to advance my aims in understanding Kant, either because I had my errors corrected by it or because, when I disagreed, I thought we might all learn from correcting errors made by intelligent and informed scholars. I hope that when people disagree with me, they do so in the same spirit. I disagreed, on one point or another, with, among others, Robert Adams, Henry Allison, Andrew Chignell, Nicholas Wolterstorff and John Hare. I mention these particular names because I consider them all my friends and colleagues; they are people I respect, from whom I have learned. Others I have not named should take for granted that my intent toward them was no different. Once again in closing I thank the contributors to this Roundtable for drawing attention to the topic of Kant on religion, from which we still have much to learn.

\section{Note}

1 Kant's writings are cited above by their conventional (if sometimes abbreviated) titles and by volume: page number in the Akademie Ausgabe. Translations are those contained in the Cambridge Edition of the Works of Immanuel Kant.

Cite this article: Wood, A. (2022). Kant and Religion Roundtable. Kantian Review 27, 101-112. https:// doi.org/10.1017/S1369415421000601 